\title{
Rainwater runoff retention on an aged intensive green roof
}

\author{
A.F. Speak ${ }^{\text {a, } * \text {, J.J. Rothwell }}{ }^{\text {a }}$, S.J. Lindley ${ }^{\text {a }}$, C.L. Smith ${ }^{\mathrm{b}}$ \\ a Geography, School of Environment and Development, The University of Manchester, Arthur Lewis Building, Oxford Road, Manchester M13 9PL, UK \\ b College of Science and Engineering, University of Leicester, Bennett Building, University Road, Leicester LE1 7RH, UK
}

\section{H I G H L I G H T S}

- Average rainfall runoff retention was $65.7 \%$ on an intensive green roof

- High organic matter content of substrate could contribute to high retention.

- High rainfall events displayed significantly reduced green roof retention.

\section{A R T I C L E I N F O}

\section{Article history:}

Received 17 January 2013

Received in revised form 26 April 2013

Accepted 28 April 2013

Available online xxxx

Editor: Simon James Pollard

\section{Keywords:}

Green roof

Sustainable urban drainage systems

Rainwater runoff

\begin{abstract}
A B S T R A C T
Urban areas are characterised by large proportions of impervious surfaces which increases rainwater runoff and the potential for surface water flooding. Increased precipitation is predicted under current climate change projections, which will put further pressure on urban populations and infrastructure. Roof greening can be used within flood mitigation schemes to restore the urban hydrological balance of cities. Intensive green roofs, with their deeper substrates and higher plant biomass, are able to retain greater quantities of runoff, and there is a need for more studies on this less common type of green roof which also investigate the effect of factors such as age and vegetation composition. Runoff quantities from an aged intensive green roof in Manchester, UK, were analysed for 69 rainfall events, and compared to those on an adjacent paved roof. Average retention was $65.7 \%$ on the green roof and $33.6 \%$ on the bare roof. A comprehensive soil classification revealed the substrate, a mineral soil, to be in good general condition and also high in organic matter content which can increase the water holding capacity of soils. Large variation in the retention data made the use of predictive regression models unfeasible. This variation arose from complex interactions between Antecedant Dry Weather Period (ADWP), season, monthly weather trends, and rainfall duration, quantity and peak intensity. However, significantly lower retention was seen for high rainfall events, and in autumn, which had above average rainfall. The study period only covers one unusually wet year, so a longer study may uncover relationships to factors which can be applied to intensive roofs elsewhere. Annual rainfall retention for Manchester city centre could be increased by $2.3 \%$ by a $10 \%$ increase in intensive green roof construction. The results of this study will be of particular interest to practitioners implementing greenspace adaptation in temperate and cool maritime climates.
\end{abstract}

(c) 2013 Elsevier B.V. All rights reserved.

\section{Introduction}

In the UK, green roofs are increasingly being recognised for their role as Sustainable Urban Drainage Systems (SUDS) (White and Alarcon, 2009). SUDS are defined as management practices designed to drain surface water in a more sustainable way than conventional systems (CIRIA, 2007). Green roofs reduce the rate and volume of runoff, and are located close to the source, thus helping to improve stormwater management. This, along with other benefits such as air pollution

\footnotetext{
* Corresponding author at: School of Environment and Development (Geography), The University of Manchester, Arthur Lewis Building, Oxford Road, Manchester M13 9PL, UK. Tel.: + 447792025678 .

E-mail address: andrew.speak@postgrad.manchester.ac.uk (A.F. Speak).
}

reduction (Speak et al., 2012), local urban cooling (Takebayashi and Moriyama, 2007), and creation of habitats for wildlife (Oberndorfer et al., 2007), means that green roofs are becoming a more prominent factor in local government planning guidelines (MCC, 2009).

Urban areas are characterised by large proportions of their surface area being impervious to rainfall runoff, which can lead to pluvial (surface water) flooding during heavy rainfall events. Recent flood management legislation in the UK has improved the priority given to pluvial flooding, as 2 million people in UK urban areas are at risk of a 1 in 200 year event (Houston et al., 2011). Climate change could lead to an increase in flooding events, because winter precipitation increases of up to $33 \%$ are predicted for the UK by the 2080s under a medium emissions scenario, especially in western parts (Murphy et al., 2009). Summer precipitation is expected to decrease, however, rainfall could 
become concentrated into intense downpours, with an increase in the frequency of 20,30, 50 and 100 year return period events for the north west UK (Sanderson, 2010).

Adaptation techniques that aim to promote infiltration and restore the urban hydrological balance include the creation of green areas such as parks, bunds and swales (CIRIA, 2007). Due to development pressures the extent to which new green spaces can be established in urban areas is generally very limited. Green roofs have the benefit of not requiring upheaval of the existing urban form, and rooftops can constitute up to $50 \%$ of the impervious area in densely built-up urban centres (Dunnett and Kingsbury, 2004).

Green roofs consist of three layers - vegetation, substrate and drainage - and two main types exist, defined by the depth of the substrate layer, with extensive roofs being generally less than $150 \mathrm{~mm}$ and intensive roofs having deeper soils. The deeper substrates on intensive roofs allow for a greater diversity and biomass of plants in the vegetation layer. The overall runoff reduction process consists of: (i) delaying the initiation of runoff; (ii) reducing the quantity of runoff; and (iii) distributing the runoff over a longer time period via slow release of excess substrate pore water (Mentens et al., 2006). The amount of rainfall that is retained is of interest to urban hydrologists and flood prediction managers.

Research on the hydrological properties of green roofs has revealed a range of average rainwater retention efficiencies. For extensive green roofs these are 45\% (DeNardo et al., 2005; Mentens et al., 2006) and 60\% (Moran et al., 2003), and cumulative annual retentions of 50\% (Stovin et al., 2012) and 60\% (VanWoert et al., 2005). Carter and Rasmussen (2006) report downfall dependent retentions of $90 \%$ for small storms and $50 \%$ for large storms. Substrate depth has a major influence due to the direct relationship between deeper substrates and higher retentions due to the enhanced storage capacity, with retentions of $75 \%$ possible on intensive roofs (Mentens et al., 2006).

A number of factors can affect the retention efficiency. The season can have a large effect, with lower rainfall totals and higher evapotranspiration rates in warmer months and therefore shorter retention capacity recharge times between rainfall events. A meta-analysis of seasonal runoff data showed runoff was significantly higher during winter $(80 \%$ of winter rainfall becoming runoff and $53 \%$ in summer) (Mentens et al., 2006). Antecedent Dry Weather Period (ADWP) is another factor related to the inter rain event recharge potential, and Stovin et al. (2012) found low ADWPs often produce low retention, however a high ADWP does not guarantee high retention due to the finite retention capacity of the roof and the influence of weather conditions during the ADWP. The intensity and duration of the rainfall is important,with small showers $(<10 \mathrm{~mm})$ being fully absorbed in a study in Texas (Simmons et al., 2008). Stovin et al. (2012) found the mean retention for 21 significant large storms to be $43 \%$, however, the total depth retained was only $29.3 \%$ of total rainfall due to lower retention in larger storms.

Slope of green roof (Getter et al., 2007), vegetation composition (Dunnett et al., 2008a) and roof position, vegetation coverage and local climate (Berndtsson, 2010) have all been stated as having an influence on green roof hydrological performance. VanWoert et al. (2005) claim the physical characteristics of the substrate layer are more important than the vegetation, and studies should attempt to investigate the properties of the substrate. Higher organic contents in mineral soils confer higher infiltration rates and holding capacities (Brady and Weil, 2008). The age of the roof can therefore become an important factor as substrate properties change over time due to build up of organic material, and macropore creation by vegetation roots or tunnelling invertebrates, which would increase retention capacity, and soil compaction which would decrease it (Getter et al., 2007). There are few examples, to date, of studies which link the soil characteristics of aged green roofs to retention capacity. This is important, as it allows estimates to be made of the future performance of green roofs as adaptation strategies for the increased flood risks caused by climate change.
The majority of green roof hydrological studies are carried out on artificial extensive green roof test beds (VanWoert et al., 2005; Dunnett et al., 2008a). There is a need therefore for research to focus on real, intensive green roofs to characterise the benefits afforded by investing in deeper substrates and to see how those benefits are maintained in a real world situation, in different seasons, and when subjected to extreme rainfall events. Similarly, as green roofing is a relatively novel technology in the UK, there is a lack of literature on how older green roofs perform, and, therefore, the implications of their use as longer-term adaptation strategies in UK urban areas is not discussed. This study aims to quantify the rainfall retention properties of an aged, intensive green roof in Manchester city centre. A comprehensive monitoring approach will be used to make a comparison between the green roof and an adjacent conventional paved roof surface, which will allow any differences in rainwater retention to be investigated for a number of different rain events.

\section{Methodology}

\subsection{Site description}

Manchester is a large city in north-west England with a population of 498,000 (MCC, 2010). The main source of flood risk to the Greater Manchester sub-region is from fluvial flooding (Kazmierczak, 2011), however surface water flooding can become more important in urban areas (DEFRA, 2008). Flooding was found to be the dominant climate impact in the region, over temperature extremes, high winds, fog and drought, with some evidence that flood events have been becoming more frequent over recent decades (Smith and Lawson, 2012). The majority of pluvial flooding events occurred during the summer months, and this may indicate the significance of short duration, heavy rainfalls characteristic of this season, and/or an increase in the impervious nature of the landscape leading to increased surface runoff (Smith and Lawson, 2012). Surface water flooding events have the potential to impact seriously on Manchester's critical and transport infrastructure (Kazmierczak, 2011), which can result in loss of power to homes and services, and large financial costs for cleanup and recovery.

A green roof within the University of Manchester campus, on the Precinct building, was chosen for the study (Fig. 1). The area is classified as open midrise, characterised by a fairly open arrangement of buildings of 3-9 storeys with some trees, typical of an inner city university campus area (Stewart and Oke, 2012). The roof was chosen because it has a conventional roof area $\left(900 \mathrm{~m}^{2}\right)$, consisting of concrete paving slabs, adjacent to a large $\left(408 \mathrm{~m}^{2}\right)$ intensive green roof, which is 43 years old, and has an average depth of $170 \mathrm{~mm}$. The roof is not within rain shadows of any adjacent taller buildings. Fig. 2 shows cross sectional representations of the two study roofs. The green roof is of fairly standard construction with the vegetation and substrate layers divided from the 'egg box' design plastic drainage layer by a fibrous membrane. The roof itself is protected by a tough geotextile membrane. The bare roof is a conventional roof surface consisting of concrete paving. The $60 \times 60 \mathrm{~cm}$ paving slabs sit on top of an insulating polystyrene cushion and a plastic foam membrane that are impermeable to water.

The green roof is of particular interest due to its age, the fact that the roof was not constructed specifically for the study, and due to it having a mineral soil substrate rather than the more usual, prefabricated, light weight aggregate (LWA) based substrate. Green roof studies with an experimental component often use specially constructed extensive green roof test rigs. It can be argued that studies of this type can over or underestimate the benefits of actual green roofs. For example, Stovin et al. (2012) recognised that the small size $\left(3 \mathrm{~m}^{2}\right)$ of their green roof setup could underestimate the lag and attenuation of their runoff hydrograph. Artificial experimentation studies can also overestimate the benefits because the test rigs are $100 \%$ green coverage, whereas in reality green roofs often have quite high proportions of conventional roof surface, 


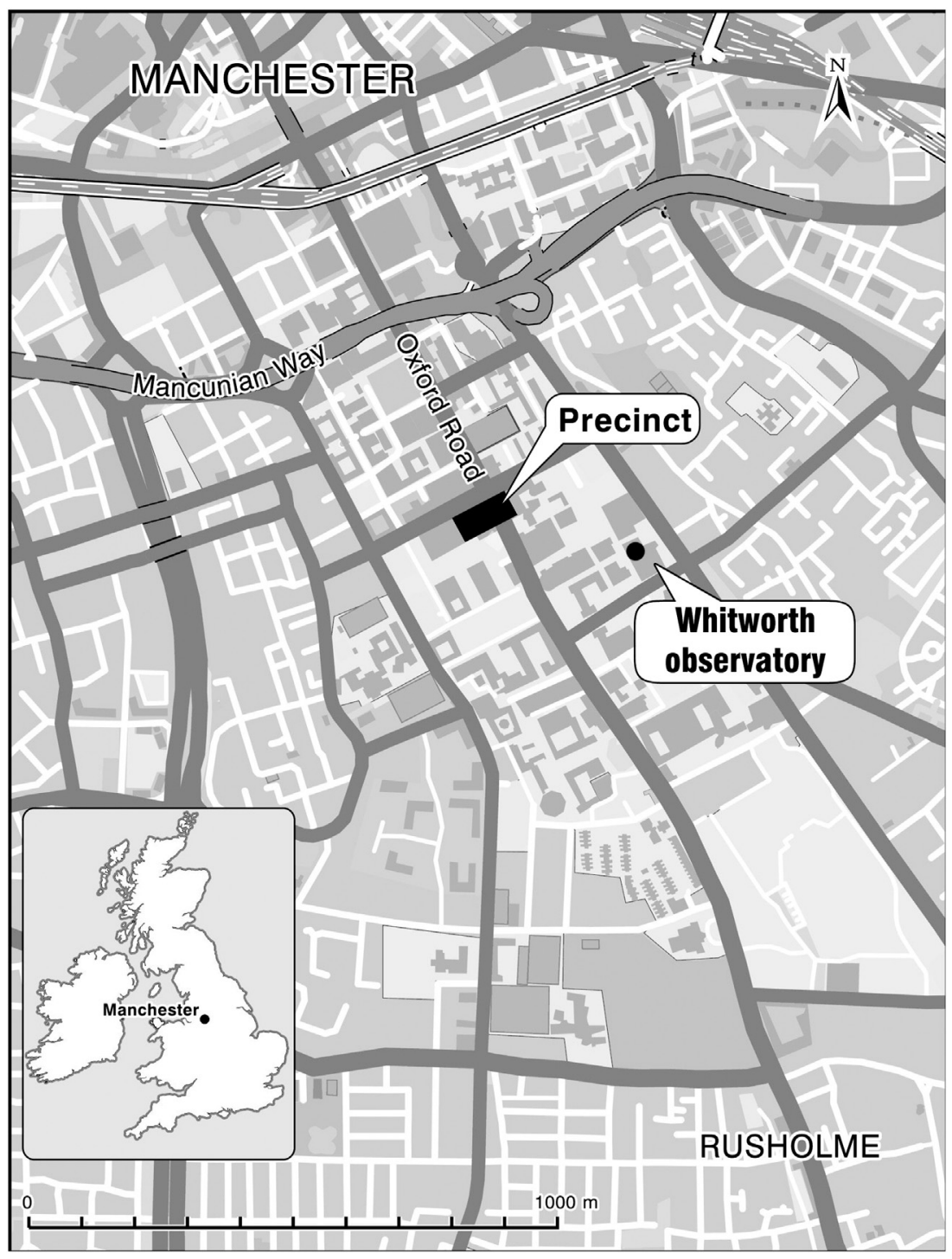

Fig. 1. Location of the study roof.

at the periphery, or to provide access for maintenance. Investigating a well established, real green roof which is subject to local weather patterns, will reveal green roof characteristics that can be sensibly applied to the real world (Fig. 3).

Table 1 reveals the vegetation on the green roof is dominated by the grasses Agrostis stolonifera and Festuca rubra, and the invasive weed Plantago lanceolata, which are generally lower in height and with thinner leaves than the less common species. While contributing to less above ground biomass per unit area, they form a substantial lower canopy. The less common species form a secondary canopy above the low lying primary canopy and in summer the vegetation can reach considerable heights over $1 \mathrm{~m}$. In winter the shrubs die back and the biomass is mostly dominated by the base canopy plants and mosses. Average surface coverage in summer is $97 \%$ and remains as high as $85 \%$ in winter due to the mosses. There are individuals of larger plants $-\mathrm{s}$ Buddleja davidii ( $2 \mathrm{~m}$ ) and Rubus fruticosus $(1 \mathrm{~m})$ in the southern part of the roof, and infrequent occurrences of up to 30 different forb species. Plant height has been shown to be significantly positively correlated with rainfall retention (Dunnett et al., $2008 \mathrm{~b}$ ) and the vegetation in the present study, with its high spatial coverage and double canopy, would be expected to have a considerable influence on retention.

\subsection{Monitoring}

Most green roof hydrological studies employ methods which divert runoff from green roof sections and quantify it via tipping rain buckets (VanWoert et al., 2005), collect it in graduated tanks (Nardini et al., 2012), or monitor the depth of water in collection tanks using a pressure transducer (Stovin et al., 2012). The structure of the precinct roof drainage system was such that collection of runoff was not practical, therefore a novel approach was employed. Square, plastic pots were constructed to sit in the top of two drainage downpipes that have a diameter of $150 \mathrm{~mm}$ - one draining the green roof section and one draining the adjacent conventional roof section (Fig. 2). Runoff entering the drains was first channelled into the pots using specially constructed plastic collars fixed into the drain openings with waterproof sealant, and water could then leave the pots via a $60^{\circ} \mathrm{v}$-notch cut into one side. Pressure transducers (Hobo water level logger U20-001-04) were placed in the pots and calibration relationships determined to relate pressure to runoff $\left(\mathrm{R}^{2}=0.91\right.$ for the green roof pot, $\mathrm{R}^{2}=0.8$ for the bare roof). Pressure was logged every minute, starting 08/09/2011 and finishing 12/10/2012. Gaps exist in the data due to logger failure from 24/09/2011 to $08 / 10 / 2011$ on the bare roof and from 20/05/ 2012 to $06 / 06 / 2012$ on both roofs. 


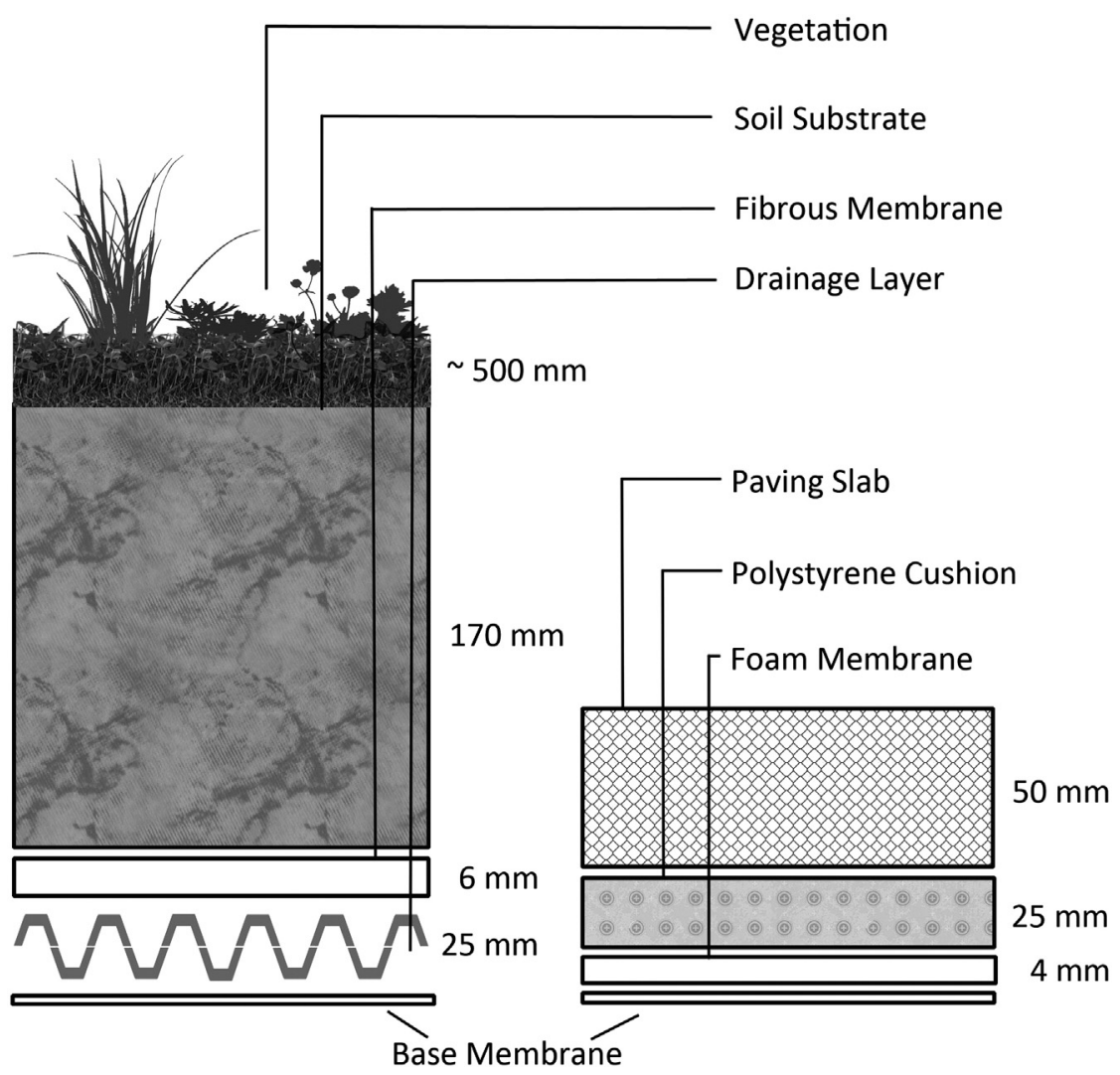

Fig. 2. Cross section of the green roof (left) and bare roof (right) showing layer depths.

Effective drainage areas for the two drains were determined from consultation with the University campus estate manager and reference to the original architectural roof survey plans. The area of the green roof catchment was estimated to be $384 \mathrm{~m}^{2}$ and the area of the bare roof was estimated at $228 \mathrm{~m}^{2}$. Both roof drainage areas include sections of a central glass atrium on the roof (Fig. 2). This means that the green roof drainage area is not entirely green and there is a significant input ( $20 \%$ of the area) from a non-green surface. Rainfall-runoff relationships for this sloping glass roof were determined for a range of different size rain events using a tipping rain bucket and subsequently used to estimate the amount of runoff on the green roof that is attributable to the atrium for each rain event.
This was then subtracted from the overall runoff measured in the drain, on an event by event basis, to gain the runoff attributable to the green component of the roof.

Rainfall data were obtained from the Whitworth Observatory (UoM, 2012), situated $150 \mathrm{~m}$ from the precinct roof (Fig. 1), which employs a Theis laser distrometer, with an accuracy of $>90 \%$ and resolution of $0.001 \mathrm{~mm} / \mathrm{h}$. The data were available as rainfall totals in 10 minute intervals, thus logger data were averaged into the same 10 min interval for analysis.

Twenty samples of the substrate layer were taken and analysed in a laboratory to determine the following parameters: soil texture (particle size analysis); field capacity (Water content after a water-saturated soil

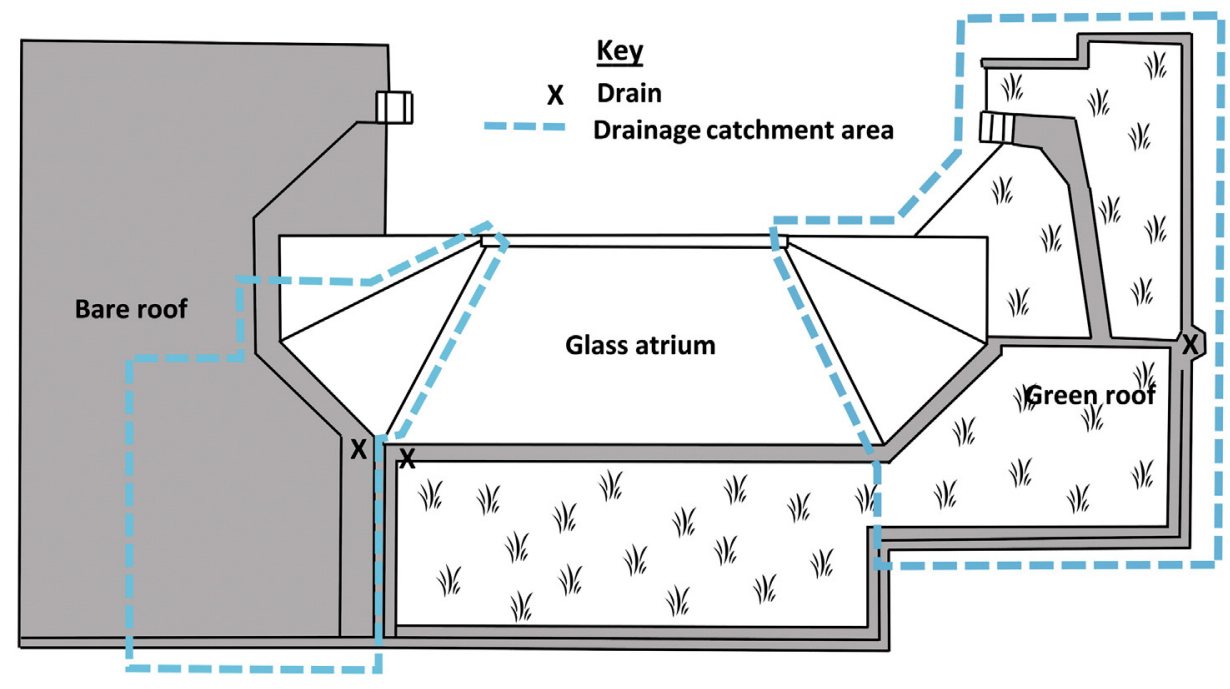

Fig. 3. Plan of the precinct roof showing drainage catchment areas for the bare and green roofs. 
Table 1

Characteristics of the dominant green roof vegetation.

\begin{tabular}{|c|c|c|c|c|}
\hline Species & $\begin{array}{l}\text { Surface } \\
\text { coverage } \\
\text { summer (\%) }\end{array}$ & $\begin{array}{l}\text { Average } \\
\text { height } \\
(\mathrm{cm})\end{array}$ & Leaf form & Duration \\
\hline Agrostis stolonifera & 30 & 15 & Narrow graminoid & Perennial \\
\hline Festuca rubra & 20 & 20 & Narrow graminoid & Perennial \\
\hline Plantago lanceolata & 20 & 10 & Rosette lanceolate & Perennial \\
\hline Senecio jacobaea & 15 & 60 & Pinnately lobed & Biennial \\
\hline Mixed: & 15 & & & \\
\hline Epilobium ciliatum & & 100 & Lanceolate & Perennial \\
\hline $\begin{array}{l}\text { Symphyotrichum } \\
\text { novi-belgii }\end{array}$ & & 100 & Lanceolate & Perennial \\
\hline Trifolium pratense & & 20 & Tri-foliate & Perennial \\
\hline Ranunculus sp. & & 30 & Tri-foliate & Perennial \\
\hline Rumex crispus & & 40 & Lanceolate & Perennial \\
\hline Various moss species & & 2 & moss & Perennial \\
\hline
\end{tabular}

sample is drained with suction in a Buchner funnel (Veihmeyer and Hendrickson, 1949)); dry bulk density (cylinder sampling method); porosity (from bulk density and particle density); and organic matter content (loss on ignition). All methods used are standard soil analysis techniques (Rowell, 1994). A Guelph permeameter was employed on the green roof to determine the saturated hydrologic conductivity, a measure of permeability. This method is acceptable once the spatial variability of soil permeability is accounted for with multiple measurements (Salverda and Dane, 1993), thus ten measurements were averaged.

\subsection{Data analysis}

Rainfall events are defined as being separated by continuous dry periods of at least six hours, in accordance with a number of previous researchers (VanWoert et al., 2005; Getter et al., 2007; Stovin et al., 2012). Consequently the study period contained 254 rainfall events, ranging from $0.01 \mathrm{~mm}$ (the lower limit of rainfall detection) to $56.08 \mathrm{~mm}$, of which 178 both produced runoff and occurred outside the periods when the loggers malfunctioned. The sensitivity of the pressure transducer to long term changes in the water levels in the runoff capture pots, and gaps in the data, means that runoff volumes were more sensibly calculated on an event by event basis, thus 69 (39\%) of the events that produced runoff, and had data, were investigated.

The events were classified as small $(<2 \mathrm{~mm})$, medium $(2-10 \mathrm{~mm})$ and large $(>10 \mathrm{~mm})$, using the criteria originally proposed by Getter et al. (2007). The events selected for analysis were composed of $25 \%$ small, 56\% medium and 19\% large. This compares favourably to the distribution of events in the whole study period, with $54 \%$ small, $30 \%$ medium and 17\% large. The lower proportion of small events in the analysed data subset arises because $54 \%$ of the small rain events did not produce runoff. Events were sampled approximately equally for each month of the study to ensure a good representation of different seasons and weather conditions. Large rain events had the potential to become significant in that they may exceed the 1 year return period rainfall for Manchester, obtained from the Flood Estimation Handbook cd-rom (NERC, 1999). In Fig. 4 it can be seen that six events fall between the 1 and 2 year return period estimation curves, and these events were looked at more closely to see how the green roof functions in extreme events.

Data were organised by season for analysis, defined as winter (Dec, Jan, Feb), spring (Mar, Apr, May), summer (Jun, Jul, Aug) and autumn (Sep, Oct, Nov). Individual months were also classified as wet, dry or average, based on their relation to the 30 year climate (Fig. 5) with those over $140 \%$ average rainfall being a wet month, less than $60 \%$ a dry month, and the rest, average months. Antecedent Dry Weather Period (ADWP), rainfall duration, rainfall depth and peak 10-minute storm intensity were recorded for each rainfall event. These were used to divide the rainfall retention data for

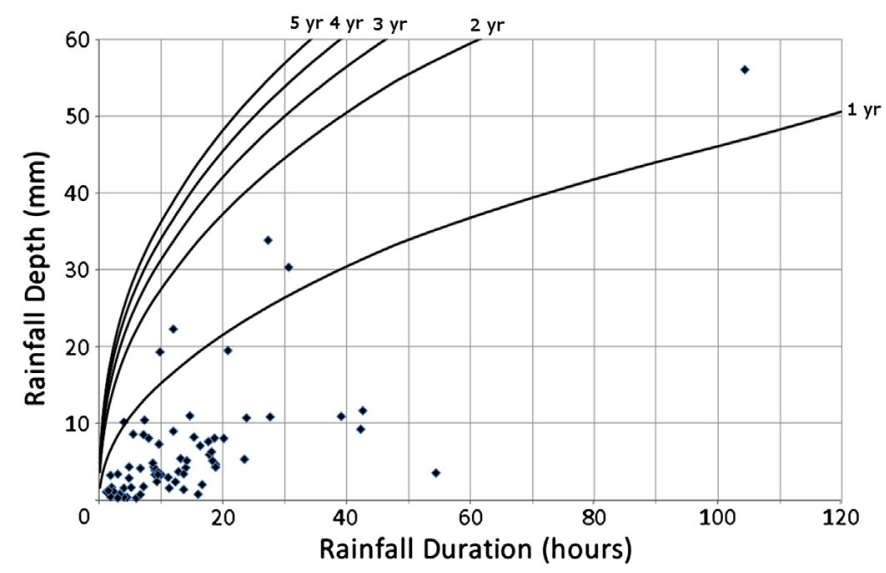

Fig. 4. Rainfall characteristics for the 69 analysed rain events with return period estimates of 1 to 5 year events for Manchester from the Flood Estimation Handbook cd-rom.

analysis. For example, events were divided into those with a short ADWP of $6-20 \mathrm{~h}$ and those over $20 \mathrm{~h}$ in accordance with Stovin et al. (2012). The division thresholds of $8 \mathrm{~mm} / \mathrm{h}$ for peak intensity and $10 \mathrm{~h}$ for duration were chosen by examining the spread of the data and choosing values which sensibly split them.

Data were checked for normality using the Anderson Darling test and green roof runoff data were normal, however the bare roof data and explanatory variables were not, hence non-parametric analyses were employed. All statistical investigations were carried out using $\mathrm{R}$ (version 2.11.1).

\section{Results}

\subsection{Climate and weather}

Greater Manchester's climate is maritime and temperate. Climate data for the period 1981-2010 show average annual rainfall to be $828.8 \mathrm{~mm}$, and these data are referred to henceforth as 'normal rainfall'. October to December is generally the wettest period (80.7$92.5 \mathrm{~mm}$ ) and February to May the driest (51.4-61.2 mm). Fig. 5 shows the monthly rain totals for the study period, with November,

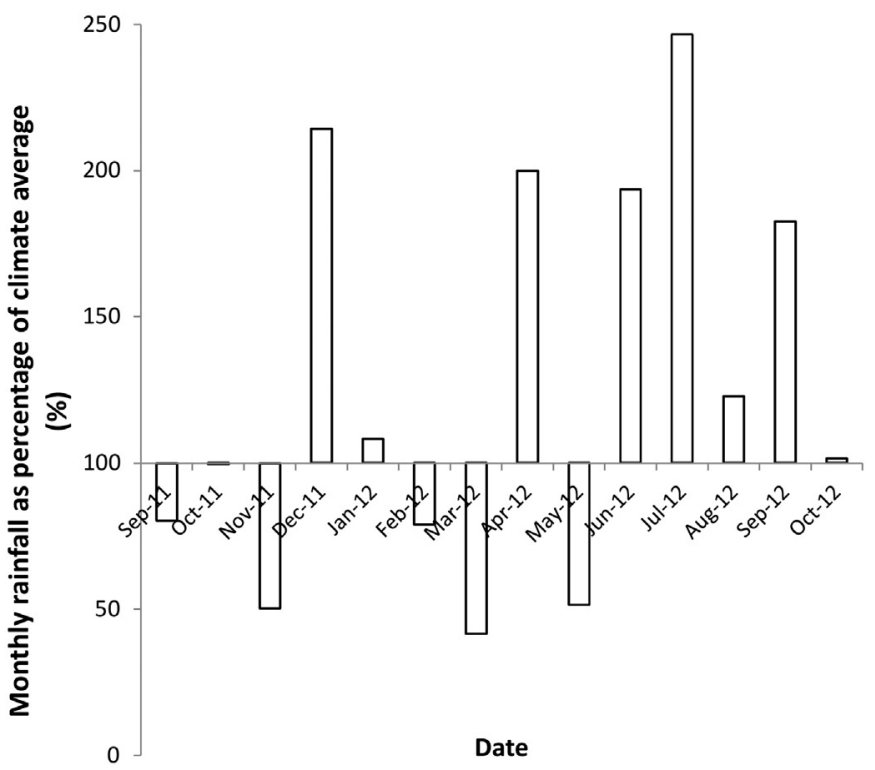

Fig. 5. Monthly rainfall expressed as a percentage of the climate average for Manchester (1981. 2010). 
Table 2

Selected soil characteristics and comparison to the FLL guideline values for an intensive green roof.

\begin{tabular}{|c|c|c|c|c|c|c|c|}
\hline & Permeability $(\mathrm{cm} / \mathrm{s})$ & $\mathrm{pH}$ & $\begin{array}{l}\text { Field Capacity } \\
\text { (max water capacity for FLL) }\end{array}$ & $\begin{array}{l}\text { Bulk Density } \\
\left(\mathrm{g} / \mathrm{cm}^{3}\right)\end{array}$ & $\begin{array}{l}\text { Particle Density } \\
\left(\mathrm{g} / \mathrm{cm}^{3}\right)\end{array}$ & $\begin{array}{l}\text { Porosity } \\
(\theta)\end{array}$ & $\begin{array}{l}\text { Organic content } \\
(\mathrm{g} / \mathrm{l})\end{array}$ \\
\hline Study roof & $1.68 \times 10^{-3}$ & 6.5 & $38 \%$ & 1.03 & 2.47 & 0.58 & 202.54 \\
\hline FLL guideline value & $5 \times 10^{-4}$ & $6-8.5$ & $45-65 \%$ & - & - & - & $<90$ \\
\hline
\end{tabular}

March and May having half the normal rainfall, but five of the months having approximately double. These wet periods mostly occurred in summer 2012, which means the study period contains an uncharacteristically wet summer. The total rainfall for the study period was $1249.6 \mathrm{~mm}$ which is $126 \%$ of the 1981-2010 climate average rainfall expected for the same 14 month period.

\subsection{Soil properties}

The soil on the intensive green roof is a sandy loam, according to the UK particle size distribution classification system. Table 2 displays the characteristics of the substrate layer, and, where possible, a comparison to the Forschungsgesellschaft Landschaftsentwicklung Landschaftsbau (FLL) guidelines for an intensive green roof (FLL, 2008). The saturated hydraulic conductivity, at $0.0017 \mathrm{~cm} / \mathrm{s}$, is quite low when compared to values from previous work, but still corresponds to a soil type with
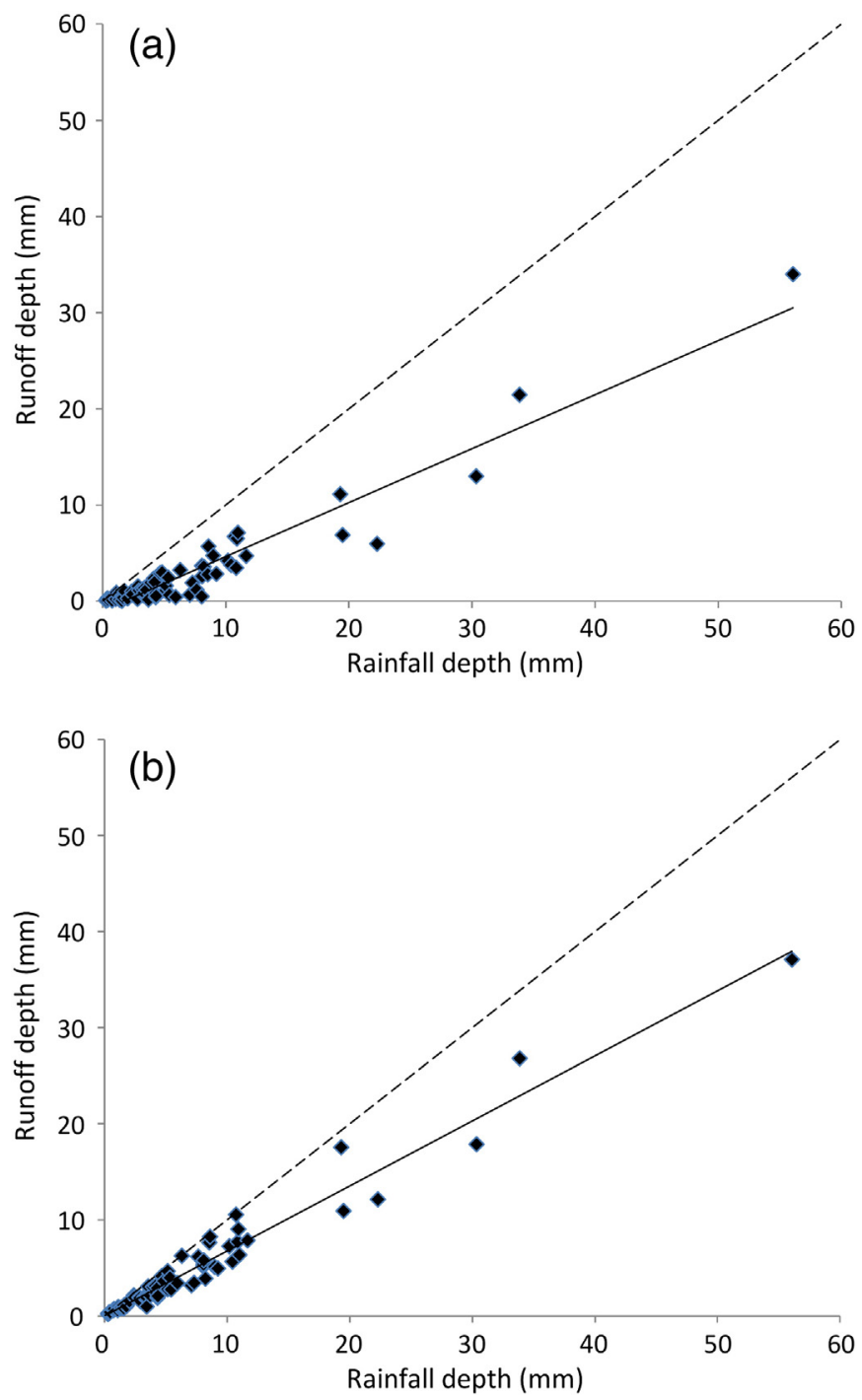

Fig. 6. Regression plot of rainfall and runoff depth for (a) bare roof and (b) green roof, with 1:1 lines included. good drainage (Terzaghi et al., 1996) and is higher than the FLL permeability guideline value of $5 \times 10^{-4} \mathrm{~cm} / \mathrm{s}$. Previously published values include $0.03 \mathrm{~cm} / \mathrm{s}$ (Bengtsson, 1995), and $0.4 \mathrm{~cm} / \mathrm{sec}$ (Nardini et al., 2012), however these are for extensive green roofs which display much higher permeability due to having substrates dominated by LWAs such as expanded slate and pumice. The bulk density was fairly low at $1.03 \mathrm{~g} / \mathrm{cm}^{3}$, with sandy loams being normally around $1.44 \mathrm{~g} / \mathrm{cm}^{3}$ (Palla et al., 2012). The low bulk density is probably attributable to the high organic content, which is much higher than the FLL guideline suggestions, and at $9 \%$ by weight, is quite high for a mineral soil. This value lies in the middle of published values, where available, which range from 3.5\% (Nardini et al., 2012) to 16\% (Palla et al., 2012). It must be stressed that the extensive roof substrates in those studies tend to be carefully designed, prefabricated mixes of LWA material with sphagnum peat additions for the organic content, as opposed to mineral soils. The soil pH of 6.5 is normal and porosity of 0.58 is fairly average.

The field capacity, at $38 \%$, is moderate. This is a laboratory determined value and in practice will not reach this. By using the same logic as Bengtsson (2005), the difference between the field capacity and the wilting point represents a volumetric storage capacity for the soil. Using a value of $9 \%$ for the wilting point of a sandy loam (Saxton et al., 1986), this means $49 \mathrm{~mm}$ storage is theoretically possible in the $170 \mathrm{~mm}$ deep substrate. Overall the soil characteristics indicate a fairly normal sandy loam mineral soil without much compaction and with high organic matter. Observations throughout the year indicate a healthy ecosystem on the roof, with earthworms, ants, butterflies, bees and birds being seen in large numbers.

\subsection{Runoff initiation}

No statistically significant difference was seen between the two roofs with regards to commencement of runoff due to the influence of the sloped glass atrium which forms a significant part of the

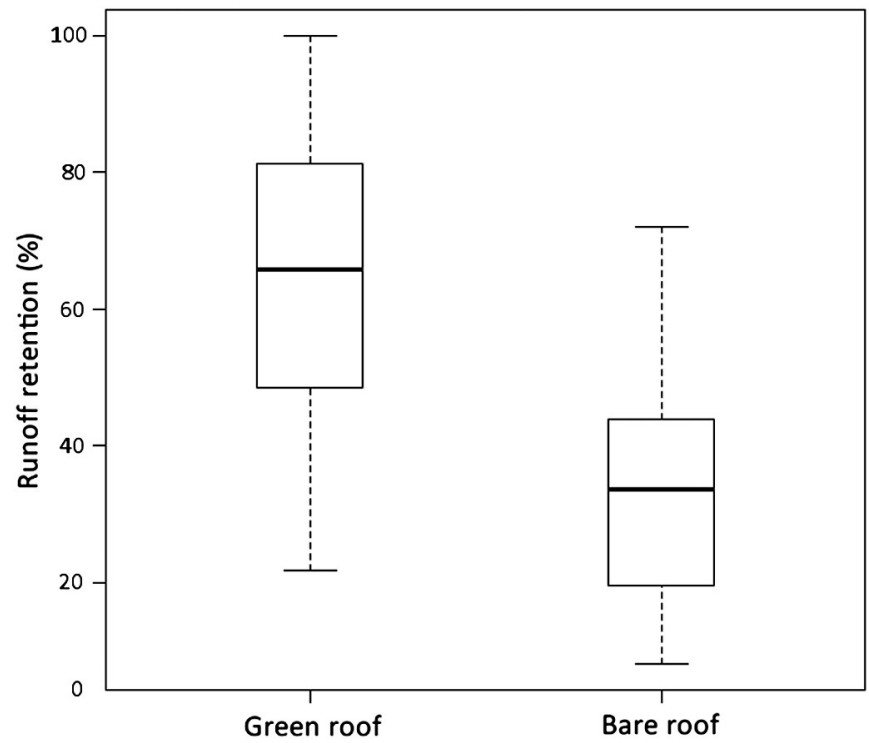

Fig. 7. Boxplot to show mean average runoff retention of all rainfall events for both roofs. 
drainage areas of both roofs, and tends to generate runoff soon after rainfall starts. The lag between the timings of peak rainfall and peak runoff was calculated for each event, however the effect of the atrium is expected to impact upon this also. Due to the discretisation of the rainfall data, the analysis is restricted to a $10 \mathrm{~min}$ resolution. Timings of runoff commencement ranged from 0 to $90 \mathrm{~min}$ on both roofs with a mean of $17.6 \mathrm{~min}$ on the green roof and 15.2 on the bare roof (medians of 10 min for both roofs).

The smallest rain event to produce runoff was $0.26 \mathrm{~mm}$ on $04 / 08$ / 2012. The ADWP for this event was only $9.5 \mathrm{~h}$ and while the previous rain event was only $0.04 \mathrm{~mm}$, there had been rain on six previous days, so the roofs would have been fairly saturated. The largest rain event that did not produce runoff was $1.81 \mathrm{~mm}$ on 26/09/2012. The ADWP for this event was only 14 hours and the previous rain event was $1.18 \mathrm{~mm}$, but this was at the start of a very warm period, so the atrium is assumed to have been quite dry. Mean ADWP for all analysed events was $30 \mathrm{~h}$.
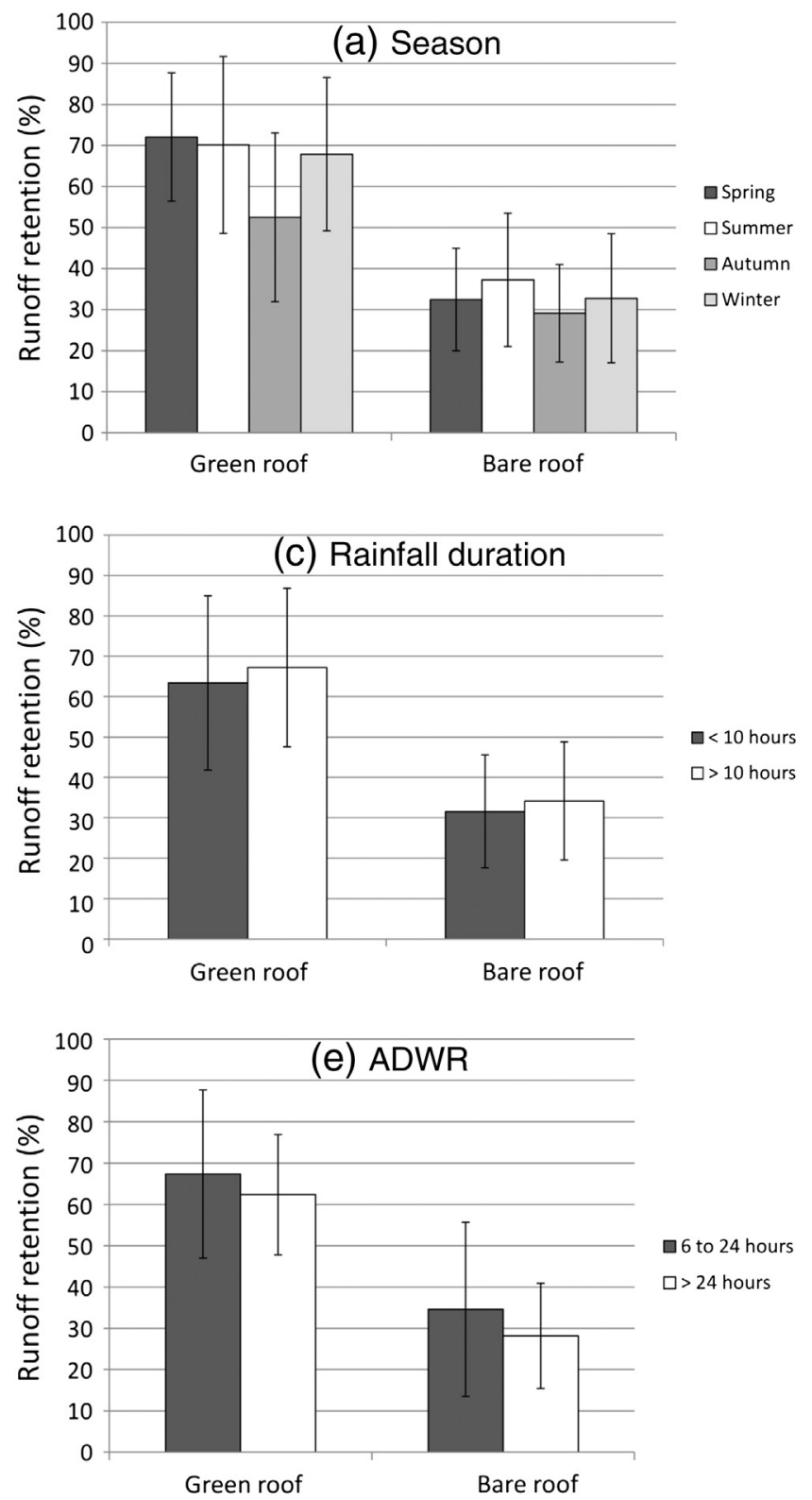

\subsection{Inter-roof comparison}

Rainfall depth versus runoff depth of the 69 analysed events for the two roofs (Fig. 6) shows runoff being generally lower on the green roof than on the bare roof. This is indicated by regression line slopes of 0.56 on the green roof and 0.68 on the bare roof, and a visual comparison with the 1:1 line. Correlations between rainfall and runoff were high, with $r=0.85$ for the green roof and $r=0.97$ for the bare roof (Spearman's rank correlation, $\mathrm{p}<0.01$ ). The box plot in Fig. 7 shows the retention, expressed as percentage of rainfall input to the roof that is retained. Median retention is higher on the green roof (65.7\%) than on the bare roof (33.6\%) and the difference is highly significant (paired Wilcoxon test, $\mathrm{V}=2408, \mathrm{p}<0.01$ ). Average runoff retained on the green roof was $4 \mathrm{~mm}$, or $2.4 \%$ of the substrate depth. There is a lot of variation within the retention data, with the green roof retaining between $22 \%$ and $100 \%$ and the bare roof between $8 \%$ and $72 \%$.
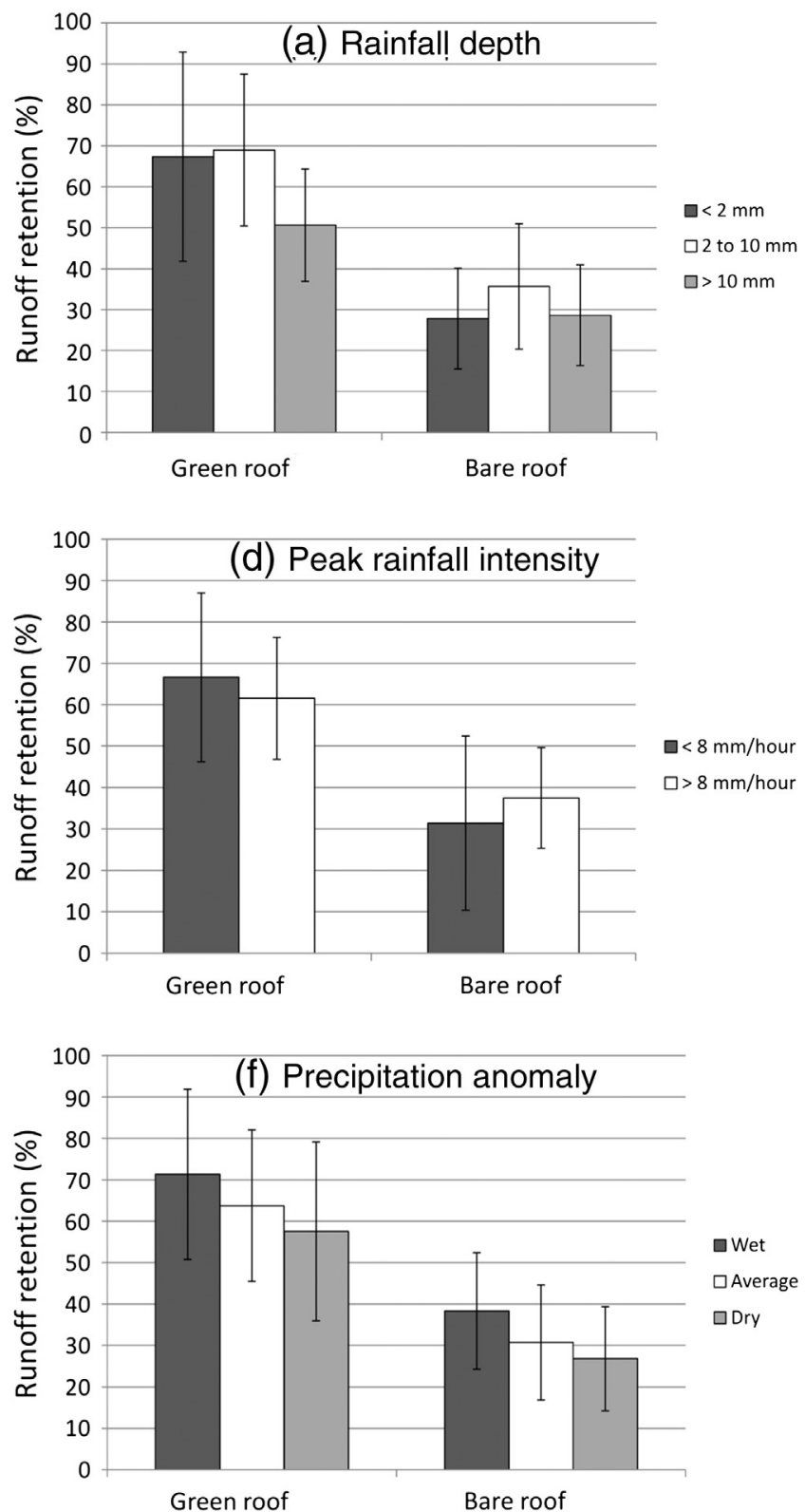

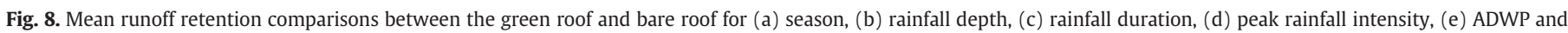
(f) precipitation anomaly. 
Fig. 8 shows the results of separating the data by the six factors, outlined in the methodology, which may influence the retention. The only significant retention influences arose on the green roof with respect to season and rainfall quantity - with retention being significantly lower in autumn (Kruskal-Wallis $\mathrm{X}^{2}=8.876, \mathrm{p}<0.05$ ) and for large rainfall events $\left(X^{2}=7.633, p<0.05\right)$. While not significant, it is interesting to note the similar pattern on both roofs in Fig. 8(f) of decreasing retention moving from wet months to dry months, contrary to what the expected trend would be. ADWP and rainfall duration also show the opposite trend to that expected, with longer durations producing higher retention (Fig. 8c) and longer ADWPs producing lower retention (Fig. 8e). These differences are small, however, and within the standard deviations.

Regression analysis using these explanatory variables was employed to see if it could be utilised as a robust tool for predicting the runoff response to any given rainfall. The scatter plots for ADWP and rainfall duration, in Fig. 9, show a large amount of scatter. Linear and non-linear (logarithmic, power and quadratic) regressions were attempted using ADWP, rainfall depth, duration and peak intensity as explanatory variables, however, they all resulted in poor $\mathrm{R}^{2}$ values and no significance. The large variation at smaller values of the explanatory variables masks any relationships that may exist. Similarly multiple regression with ADWP, peak rainfall and duration was found to be non significant $\left(\mathrm{R}^{2}=0.04, \mathrm{~F}=1.014, \mathrm{p}=0.39\right)$.
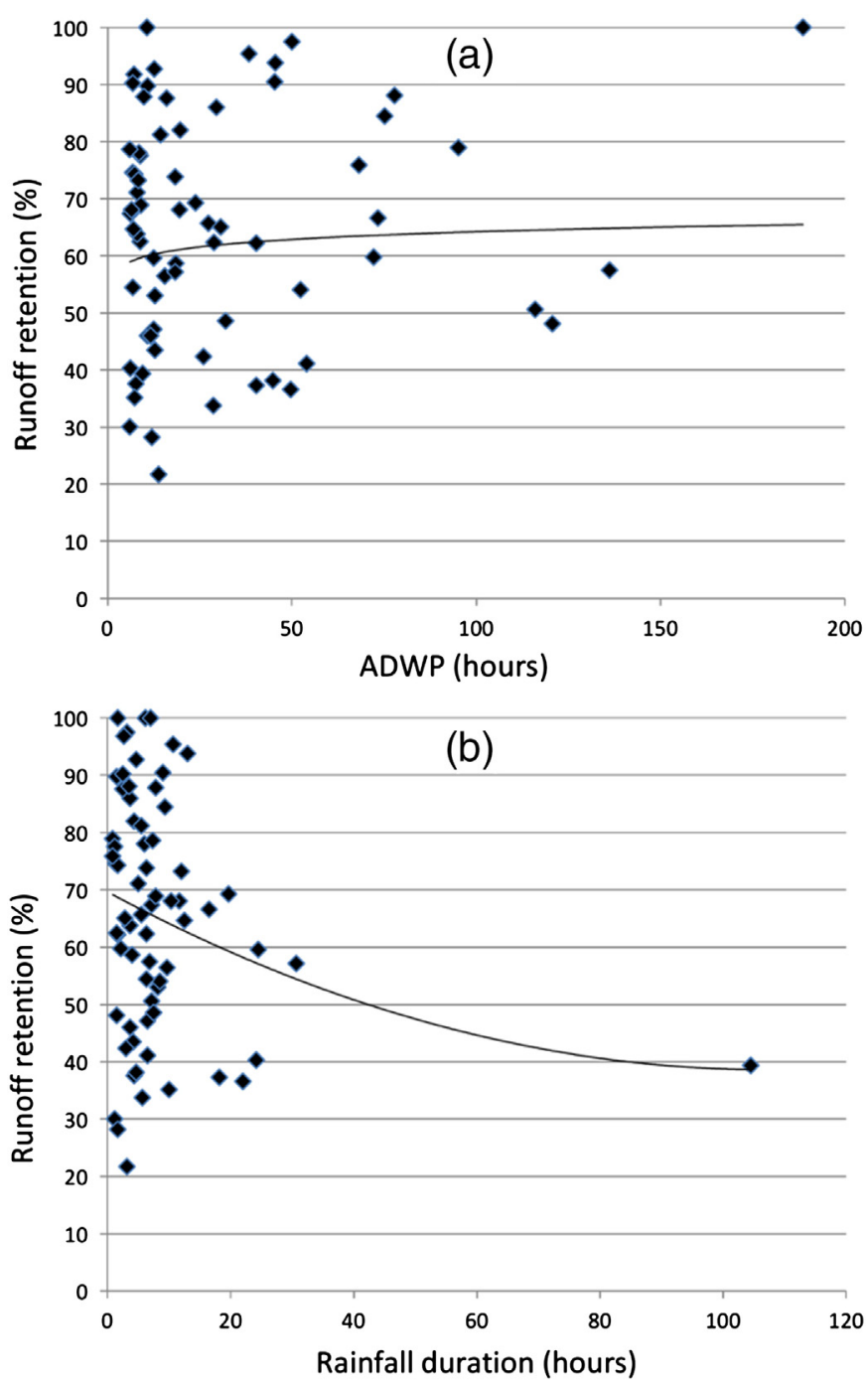

Fig. 9. Regression plots of runoff retention against (a) ADWP and (b) rainfall duration, for the green roof, with quadratic regression equation lines shown.

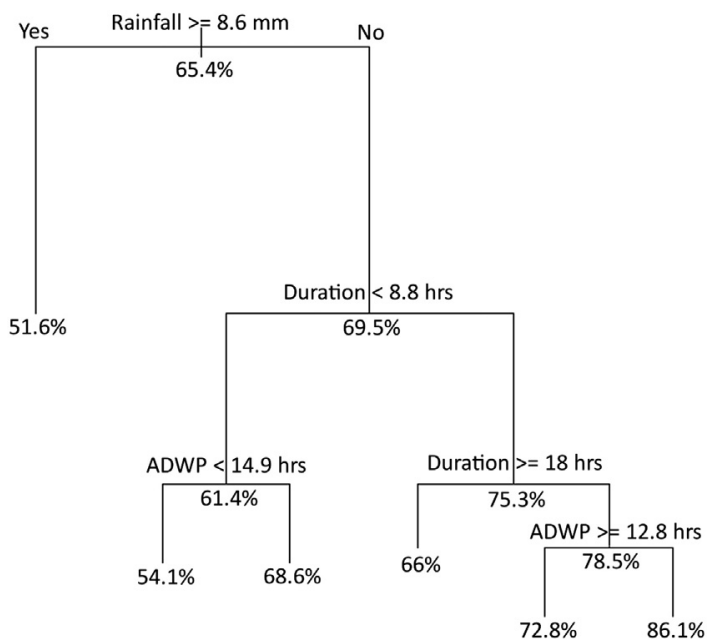

Fig. 10. Regression tree for runoff retention percentage on the green roof. 'Yes' and 'no' splits are assigned to left and right respectively.

The data were subjected instead to non-parametric CART (Classification and Regression Tree) analysis. Models were fitted using binary recursive splitting of the data set into increasingly homogeneous subsets and the resulting tree can be seen in Fig. 10. Rainfall is seen to be the primary determinant of retention with larger rainfalls producing low retention, and smaller rainfalls leading to further branches. Peak intensity was excluded by the analysis. ADWP and duration both produce conflicting branches which reflects the complicated interactions within the data. For instance, to get to the highest retention figure of $86.1 \%$ requires a rainfall below $8.6 \mathrm{~mm}$, ADWP greater than 12.8 hours, and a duration less than 8.8 hours, which make sense, but a duration greater than 18 hours is also indicated.

\subsection{Storm events}

The six events with rainfall/duration characteristics that exceed those of 1 year return period events are summarised in Table 3. The largest retention depth in the study was $22.07 \mathrm{~mm}$ for the storm event starting 02/12/2011. The bare roof also had quite high retention for this event, but the rainfall duration was very long, at $105 \mathrm{~h}$, so the rainfall was very prolonged with brief dry periods $(<6 \mathrm{~h})$ within it during which the roof could dry out a little. This maximum depth equates to $13 \%$ of the substrate depth, which is much lower than the $25 \%$ achieved in Stovin et al. (2012). Four of the events occurred in the summer period, and represent convectional storms.

The mean retention of the storm events on the green roof is $51.2 \%$, which is lower than the mean of all the study events, however, retentions are quite variable and one significant storm event $(22.3 \mathrm{~mm})$ displayed retention of $73.2 \%$. Bare roof retentions, at $30 \%$ on average, are similar to those in the rest of the study. Further evidence that ADWP is not a very good predictor of retention capacity comes from the 23/09/2012 event, which had the longest ADWP of the six storms at just over two days, but the lowest retention, probably because the rainfall was the second largest of the study.

\section{Discussion}

\subsection{Retention efficiency}

The median retention of $65.7 \%$ achieved by the intensive green roof is lower than the median of eleven intensive roof studies of $75 \%$ found in the meta-analysis undertaken by Mentens et al. (2006). This is potentially due to the unusually wet summer in the study period, with above average rainfall from June to September. Schroll et al. (2011) noted that cold, wet environments can be 
Table 3

Selected characteristics of the 6 storm events greater than 1 year return period.

\begin{tabular}{|c|c|c|c|c|c|c|c|c|c|}
\hline Event & $\begin{array}{l}\text { Total Rain } \\
(\mathrm{mm})\end{array}$ & $\begin{array}{l}\text { Rain duration } \\
\text { (hh:mm) }\end{array}$ & $\begin{array}{l}10 \mathrm{~min} \text { peak } \\
\text { rainfall intensity } \\
(\mathrm{mm} / \mathrm{hr})\end{array}$ & $\begin{array}{l}\text { ADWP } \\
\text { (hh:mm) }\end{array}$ & $\begin{array}{l}\text { \% Retention } \\
\text { green roof }\end{array}$ & $\begin{array}{l}\text { \% Retention } \\
\text { bare } \\
\text { roof }\end{array}$ & $\begin{array}{l}\text { Retention } \\
\text { depth } \\
\text { green roof }(\mathrm{mm})\end{array}$ & $\begin{array}{l}\text { Retention as } \\
\% \text { of substrate } \\
\text { depth }\end{array}$ & $\begin{array}{l}\text { Retention depth } \\
\text { bare roof (mm) }\end{array}$ \\
\hline $02 / 12 / 2011$ & 56.08 & 104:30 & 18.66 & $9: 30$ & 39.36 & 33.85 & 22.07 & 12.98 & 18.98 \\
\hline 06/07/2012 & 22.30 & $12: 00$ & 9.06 & $8: 20$ & 73.22 & 45.59 & 16.33 & 9.61 & 10.17 \\
\hline $19 / 07 / 2012$ & 30.35 & $30: 40$ & 22.5 & $18: 20$ & 57.15 & 41.12 & 17.34 & 10.20 & 12.48 \\
\hline $24 / 08 / 2012$ & 10.19 & 4:00 & 9.96 & $18: 30$ & 58.65 & 28.80 & 5.97 & 3.51 & 2.93 \\
\hline $29 / 08 / 2012$ & 19.31 & $9: 50$ & 68.22 & $26: 00$ & 42.33 & 11.81 & 8.17 & 4.81 & 2.28 \\
\hline $23 / 09 / 2012$ & 33.87 & $27: 20$ & 6.36 & $49: 50$ & 36.58 & 20.88 & 12.39 & 7.29 & 7.07 \\
\hline
\end{tabular}

challenging ones for green roof retention performance. The green roof would not have had much chance to restore its retention potential between rain events, despite expected higher evapotranspiration rates in summer from the greater plant biomass and elevated air temperatures. None the less, this figure is higher than retentions for extensive green roofs, previously quoted. Therefore the age of the roof does not appear to have deleteriously affected the retention ability of the green roof. This could be attributed to the high organic matter content that will have accumulated over 43 years of plant growth. The maintenance regime on the green roof has ensured minimum disturbance to the substrate layer. Getter et al. (2007) found organic matter doubled in a green roof over 5 years which increased the porosity and the water capacity of the roof. Therefore green roofs might be expected to improve some hydrological benefits with time, and indeed many of the soil properties were indicative of a normal substrate (Table 2).

Anecdotal observations of a thriving green roof ecosystem provide evidence that the green roof was in a healthy ecological state. Earthworms are vital for the incorporation of fresh plant material into the soil structure but they are rare on extensive roofs due to lack of protection from winter frosts in the thin substrate. Additionally, deeper substrates are preferable because they reduce drought stress on the vegetation and allow a broader selection of roof plants, away from the traditional monocultures of sedum plants found on extensive roofs. There is evidence that runoff is reduced more by taller plants with denser root systems (Dunnett et al., 2008a, 2008b) and grasses can be more effective than sedum and forbs (Nagase and Dunnett, 2012). The larger biomass on intensive green roofs will also increase the other benefits such as air pollution reduction (Speak et al., 2012).

The green roof retention is double the average retention of $33.6 \%$ on the bare roof. The paved roof used in this study is not as common a roof surface as other forms of conventional roof, such as gravel roofs with $24 \%$ retention and traditional smooth roofs with $15 \%$ retention (Mentens et al., 2006). The increased retention may arise from the roughness of the paving slab surfaces but mostly from the increased surface area brought about by the cushions and foam membrane underneath the paving slabs (Fig. 2). While this roof is interesting so far as it provides information on a different form of roof structure, it must be remembered that most typical urban roof surfaces have less retention capacity than the bare roof reported here. Consequently, the relative green roof retention demonstrated in this study would be greater when compared to more common roof surfaces.

As this study was carried out on a real roof, certain peculiarities unique to this roof had to be taken into account, especially the fact that the green roof drain had a significant impact from the glass atrium roof. It is expected that the minimum rain to produce runoff and maximum rain to not produce runoff would have been quite different, without the atrium influence. It also had the effect of removing the delay effect seen in most previous studies (VanWoert et al., 2005; Berndtsson, 2010; Fioretti et al., 2010). Urban drains often receive runoff inputs from heterogeneous sources and it is interesting to note that just $20 \%$ of the catchment area being non-green was sufficient to bring the mean peak delay on the green roof closer to that of the bare roof. However, it must be noted that the paved roof in this study, with its apparent increased storage capacity relative to other conventional roof surfaces, would likely delay runoff initiation in comparison to these other surfaces. The evidence from this study shows that green roof installations with the aim of delaying and attenuating peak runoff must achieve in excess of $80 \%$ vegetation cover over the roof catchment in order to have any effect. However, where this isn't possible there are still benefits to be gained from improved retention rates.

Bengtsson (2005) described runoff generation only beginning once field capacity is reached in the substrate of an extensive roof, with storage being equal to the field capacity minus the wilting point - when the moisture fraction in the substrate is soil-bound. The theoretical holding capacity of around $49 \mathrm{~mm}$ of rain, predicted by this method, was not reached in practice, with retentions of on average $4 \mathrm{~mm}$ found and a maximum of $12 \mathrm{~mm}$. This could be because the above average rainfall during a large part of the study prevented the substrate layer from drying out to levels capable of retaining such large inputs of rainfall. The intensive roof would be expected to retain the majority of a given depth of rainfall, below $49 \mathrm{~mm}$, but so many other factors are involved that it has proved difficult to predict.

Significantly lower retention was seen on the green roof in autumn, when there was above average rainfall. High rainfall events lowered the retention capacity of the green roof as the substrate became saturated. Carter and Rasmussen (2006) also found large rain events produced lower retention. Multiple regression with explanatory variables was carried out to see if it could be a robust modelling tool for estimating the runoff response of storm events on green roofs. Similar to Stovin et al. (2012), explanatory variables did not have a clear influence on retention. ADWP should in theory be a good predictor of retention capacity, as was found in a study on extensive roofs displaying $82 \%$ average runoff reduction by event (Voyde et al., 2010), but the interaction of the other factors, such as seasonal effects on evapotranspiration, produces too much variation in the results to pick out clear individual trends. This also manifested in the CART analysis, with duration greater than $18 \mathrm{~h}$, which in theory should lessen retention, included among the criteria which produce the largest retention. A continuous simulation moisture flux model, proposed by Stovin et al. (2012) is preferable to regression based methods. This conceptual approach takes into account rainfall inputs and moisture fluxes out of the substrate via runoff, or evapotranspiration during ADWPs, to predict the available retention depth in the substrate and therefore how it may be expected to respond to further rain inputs.

Contrary to expectations, season was found to have not as strong an effect on retention for the period of this study. Except for autumn, as discussed above, the seasons displayed very similar retention averages. Schroll et al. (2011) found a medium-only treatment did not significantly differ in retention to an extensive green roof in winter but summer differences were significant with $65 \%$ retention on the green roof. In summer the lush, tall vegetation on intensive roofs should dramatically increase evapotranspiration rates, however, in an anomalously wet summer this effect may be masked by the above average rainfall or the plants may be adversely affected by waterlogged conditions. The highest retention values of the events in the present study were achieved in summer, with two instances 
of complete retention on the green roof, and $72 \%$ retention on the bare roof. A median retention of 70\% in summer (Fig. 8a) is still an encouraging result, and permits the consideration of green roofs as a measure to mitigate the impact of heavy summer downpours.

The extreme events in the study enabled an assessment of an intensive green roof's ability to cope and the retention was considerable. The age of the roof is not an issue affecting the effectiveness of green roofs as an adaptation measure. The case may be different for extensive roofs, and longitudinal studies could help to reveal any significant changes occurring in LWA substrates.

\subsection{Implications for manchester city centre}

Using the roof quantification work of Speak et al. (2012) the green roof spatial extent potential of Manchester city centre and the Oxford Road corridor, is approximately 50 ha of the total 326 ha. A feasible green roof construction scenario of $10 \%$ (14.9 ha) of Manchester's roofs can be postulated. With $65.7 \%$ average rainfall retention for an intensive roof, and employing retention estimates from Mentens et al. (2006) of $45 \%$ on extensive roofs and $15 \%$ on traditional roofs, the increased retention of green roofs over bare roofs for an average year's rainfall can be estimated. Intensive roofs retain $2.3 \%$ more of the rainfall falling on the selected inner city zone, and extensive roofs $1.3 \%$. This is comparable to the figure for an identical hypothetical green roof construction scenario, in Brussels, which found runoff was reduced by $2.7 \%$ using extensive roofs (Mentens et al., 2006).

Although these figures may at first seem low, it highlights that green roofs alone cannot be relied upon to provide all the SUDS benefits in a city because flat roofs are a limited resource within urban areas (Carter and Jackson, 2007). However, one must also remember that green roofs have multiple benefits stretching beyond their hydrological function. Intensive roofs, in particular, should be considered by city planners because they offer a higher retention capacity compared to conventional roof covers, and the potential for varied and lush vegetation.

\section{Conclusion}

- Hydrological monitoring of urban roof drainage was achieved using a compact v-notch weir methodology.

- Average runoff retention of $65.7 \%$ was achieved on an intensive green roof, compared to $33.6 \%$ on an adjacent paved roof.

- Organic matter content in the 43 year old roof substrate was relatively high, leading to an increase in the retention capacity of the roof.

- Season and rainfall amount had significant impacts on retention, however, many other explanatory variables such as ADWP and peak rainfall intensity had no demonstrable, significant impact.

- Intensive roof construction on $10 \%$ of the rooftops in Manchester city centre would increase annual rainfall retention by $2.3 \%$.

\section{Acknowledgments}

This work was funded by NERC with CASE contributions from Manchester City Council. Advice and assistance was gratefully received from John Moore, Gregory Lane-Serff and Clive Agnew at the University of Manchester, and Virginia Stovin at the University of Sheffield. The botanical survey of the roof was carried out by Cameron Crook.

\section{References}

Bengtsson L. Peak flows from thin sedum-moss roof. Nord Hydrol 1995;36(3):269-80. Berndtsson JC. Green roof performance towards management of runoff water quantity and quality: a review. Ecol Eng 2010;36(4):351-60.
Brady NC, Weil RR. The nature and properties of soils. 14th ed. Harlow: Prentice Hall; 2008.

Carter T, Jackson CR. Vegetated roofs for stormwater management at multiple spatial scales. Landsc Urban Plan 2007;80(1-2):84-94.

Carter TL, Rasmussen TC. Hydrologic behavior of vegetated roofs. J Am Water Resour Assoc 2006;42(5):1261-74.

CIRIA. C697, The SUDS Manual. Construction Industry Research and Information Association; 2007 [www.ciria.org]

DEFRA. Making Space for Water. Urban flood risk \& integrated drainage (HA2). IUD pilot summary report. London: Halcrow Group Ltd \& Defra; 2008. [June 2008].

DeNardo JC, Jarrett AR, Manbeck HB, Beattie DJ, Berghage RD. Stormwater mitigation and surface temperature reduction by green roofs. Trans ASAE 2005:48(4):1491-6.

Dunnett N, Kingsbury N. Planting Green Roofs and Living Walls. Portland: Timber Press; 2004.

Dunnett N, Nagase A, Booth R, Grime P. Influence of vegetation composition on runoff in two simulated green roof experiments. Urban Ecosyst 2008a;11(4):385-98.

Dunnett N, Nagase A, Hallam A. The dynamics of planted and colonising species on a green roof over six growing seasons 2001-2006: influence of substrate depth. Urban Ecosyst 2008b;11(4):373-84.

Fioretti R, Palla A, Lanza LG, Principi P. Green roof energy and water related performance in the Mediterranean climate. Build Environ 2010;45(8):1890-904.

FLL. Forschungsgesellschaft Landschaftsentwicklung Landschaftsbau e. V. (FLL) Guidelines for the Planning, Construction and Maintenance of Green Roofing. English language edition; 2008 [available at www.fll.de ed. FLL, Bonn].

Getter KL, Rowe DB, Andresen JA. Quantifying the effect of slope on extensive green roof stormwater retention. Ecol Eng 2007;31(4):225-31.

Houston D, Werritty A, Bassett D, Geddes A, Hoolachan A, McMillan M. Pluvial (rain-related) flooding in urban areas: the invisible hazard. York: Joseph Rowntree Foundation; 2011. [Available at: www.jrf.org.uk/publications].

Kazmierczak, A. K., C. (2011). Risk of flooding to infrastructure in Greater Manchester. In: EcoCities project, M., UK. (ed.).

MCC. Greater Manchester green roof programme: feasibility study. Part 1 Report: Scoping \& Work Programme Development. Manchester City Council; 2009. [http://neweconomymanchester.com/stories/840-other_publications].

MCC. Manchester's population historically [Online]. Available: http://www.manchester. gov.uk/downloads/download/4220/corporate_research_and_intelligence_population_ publications 2010. [Accessed January 2012].

Mentens J, Raes D, Hermy M. Green roofs as a tool for solving the rainwater runoff problem in the urbanized 21st century? Landsc Urban Plan 2006;77(3):217-26.

Moran A, Hunt B, Jennings G. A North Carolina field study to evaluate greenroof runoff quality, runoff quantity, and plant growth. ASAEPaper 032303Am. Soc. of Agric. Eng.; 2003 [St. Joseph,MI].

Murphy JM, Sexton DMH, Jenkins GJ, Boorman PM, Booth BBB, Brown CC, et al. UK climate projections science report. Climate change projections. Exeter, UK: Met Office Hadley Centre; 2009. [192 pp.].

Nagase A, Dunnett N. Amount of water runoff from different vegetation types on extensive green roofs: effects of plant species, diversity and plant structure. Landsc Urban Plan 2012;104(3-4):356-63.

Nardini A, Andri S, Crasso M. Influence of substrate depth and vegetation type on temperature and water runoff mitigation by extensive green roofs: shrubs versus herbaceous plants. Urban Ecosyst 2012;15(3):697-708.

NERC. (Natural Environment Research Council - Centre for Ecology and Hydrology) The flood estimation handbook (FEH) CD; 1999.

Oberndorfer E, Lundholm J, Bass B, Coffman RR, Doshi H, Dunnett N, et al. Green roofs as urban ecosystems: ecological structures, functions, and services. Bioscience 2007;57(10):823-33.

Palla A. Gnecco I, Lanza LG. Compared performance of a conceptual and a mechanistic hydrologic models of a green roof. Hydrol Processes 2012;26(1):73-84.

Rowell DL. Soil science: methods and applications. Harlow, Essex: Longman Group UK Ltd. 1994.

Salverda AP, Dane JH. An examination of the Guelph Permeameter for measuring the soils hydraulic properties. Geoderma 1993;57(4):405-21.

Sanderson M. Changes in the frequency of extreme rainfall events for selected towns and cities. For Ofwat, produced by the Met Office; 2010.

Saxton KE, Rawls WJ, Romberger JS, Papendick RI. Estimating generalized soil-water characteristics from texture. Soil Sci Soc Am J 1986;50(4):1031-6.

Schroll E, Lambrinos J, Righetti T, Sandrock D. The role of vegetation in regulating stormwater runoff from green roofs in a winter rainfall climate. Ecol Eng 2011;37(4):595-600.

Simmons MT, Gardiner B, Windhager S, Tinsley J. Green roofs are not created equal: the hydrologic and thermal performance of six different extensive green roofs and reflective and non-reflective roofs in a sub-tropical climate. Urban Ecosyst 2008;11(4): 339-48.

Smith C, Lawson N. Identifying extreme event climate thresholds for greater Manchester, UK: examining the past to prepare for the future. Meteorol Appl 2012;19(1): $26-35$.

Speak AF, Rothwell JJ, Lindley SJ, Smith CL. Urban particulate pollution reduction by four species of green roof vegetation in a UK city. Atmos Environ 2012;61:283-93.

Stewart ID, Oke TR. Local climate zones for urban temperature studies. Bull Am Meteorol Soc 2012;93:1879-900.

Stovin V, Vesuviano G, Kasmin $\mathrm{H}$. The hydrological performance of a green roof test bed under UK climatic conditions. J Hydrol 2012;414-415:148-61.

Takebayashi H, Moriyama M. Surface heat budget on green roof and high reflection roof for mitigation of urban heat island. Build Environ 2007;42(8):2971-9.

Terzaghi K, Peck RB, Mesri G. Soil mechanics in engineering practice. 3rd ed. New York: John Wiley \& Sons; 1996. 
UoM. University of Manchester - The Whitworth Meteorological Observatory [Online] Available: http://www.cas.manchester.ac.uk/restools/whitworth/data/. [Accessed March 2012].

VanWoert ND, Rowe DB, Andresen JA, Rugh CL, Xiao L. Watering regime and green roof substrate design affect Sedum plant growth. Hortscience 2005;40(3):659-64.

Veihmeyer FJ, Hendrickson AH. Methods of measuring field capacity and permanent wilting percentage of soils. Soil Sci 1949;68(1):75-94.
Voyde E, Fassman E, Simcock R. Hydrology of an extensive living roof under sub-tropical climate conditions in Auckland, New Zealand. J Hydrol 2010;394(3-4):384-95.

White I, Alarcon A. Planning policy, sustainable drainage and surface water management: a case study of Greater Manchester. Built Environ 2009;35(4):516-30. 